\title{
InAIGaN LASER DIODES GROWN BY PLASMA ASSISTED MOLECULAR BEAM EPITAXY
}

\author{
C. Skierbiszewski a, ${ }^{\text {, }}$, M. Siekacz ${ }^{\text {a, }}$, H. Turski ${ }^{\text {a }}$, M. Sawicka a ${ }^{\text {, A. Feduniewicz-Żmuda }}{ }^{\text {a }}$ \\ P. Perlin ${ }^{\text {a,b }}$, T. Suski a ${ }^{\text {, Z. Wasilewski }}{ }^{\text {, }}$, I. Grzegory $^{\text {a }}$, and S. Porowski ${ }^{\text {a }}$ \\ ${ }^{a}$ Institute of High Pressure Physics, Polish Academy of Sciences, Sokołowska 29/37, 01-142 Warszawa, Poland \\ E-mail: czeslaw@unipress.waw.pl \\ ${ }^{\mathrm{b}}$ TopGaN Ltd, Sokołowska 29/37, 01-142 Warszawa, Poland \\ ' Institute for Microstructural Sciences, National Research Council, 1200 Montreal Road, Ottawa, K1A 0R6 Canada
}

Received 28 August 2011; accepted 1 December 2011

\begin{abstract}
We present recent progress in the growth of nitride-based laser diodes (LDs) made by plasma assisted molecular beam epitaxy (PAMBE). This technology is ammonia-free, and nitrogen for the growth is activated by RF plasma source from nitrogen molecules. The demonstration of continuous wave blue-violet InGaN LDs has opened a new perspective for PAMBE in optoelectronics. We demonstrate the laser diodes grown by PAMBE operating at the range from $410 \mathrm{~nm}$ to $455 \mathrm{~nm}$. The key factors which allow us to extend the lasing wavelength to $455 \mathrm{~nm}$ are (a) improvements in the growth of InGaN quantum wells with high nitrogen flux in PAMBE, and (b) design of the laser diode structure. We also report on optically pumped lasing at $501 \mathrm{~nm}$ on InGaN laser structures which show that there are no intrinsic limitations in PAMBE technology for the growth of green LDs.
\end{abstract}

Keywords: GaN, laser diodes, molecular beam epitaxy, InGaN growth

PACS: 78.55.Cr, 78.67.De, 81.15.Hi

\section{Introduction}

True blue and green nitride laser diodes (LDs) are one of the key challenges for the epitaxy of nitrides due to a variety of its potential applications like e.g. TV projectors, medicine diagnostics, environmental protection. Very recently, green LDs at 500-530 nm have been demonstrated in nitride-based structures grown by metal organic vapour phase epitaxy (MOVPE) either on polar, semi-polar and non-polar substrate orientations [1-5]. MOVPE is a leading technology in the field of nitride structures for optoelectronic devices $[1,2]$; however, the progress in understanding the new growth mechanism for nitrides in plasma assisted molecular beam epitaxy (PAMBE) has led to the demonstration of blue-violet laser diodes [6,7], which in turn has renewed interest in MBE technology. For ammonia-free PAMBE, the growth mechanism is entirely different from that in MOVPE and allows the growth of device-quality nitride structures at temperatures lower by $300{ }^{\circ} \mathrm{C}$ versus those used in MOVPE [6-11]. Therefore, it is highly interesting whether PAMBE can be useful for high In content structures required for true blue and green emitters.

In this work, we demonstrate (a) optically pumped lasing from single quantum well (SQW) InGaN laser structures in the range of 409$501 \mathrm{~nm}$; (b) LDs grown by PAMBE in the range of 410-455 nm.

\section{Experiment}

The growth of all nitride laser structures presented in this work was performed in a customised VG90 $\mathrm{MBE}$ reactor equipped with two Veeco RF plasma sources operating at $240-450 \mathrm{~W}$ for $0.8-2 \mathrm{~cm}^{3} / \mathrm{min}$ of $\mathrm{N}_{2}$ flow. The pressure during growth was $1.5-7 \cdot 10^{-5}$ Torr. The substrates used were either high pressure grown bulk GaN or bulk GaN made by hydrate vapour phase epitaxy (HVPE). The epi-ready bulk substrates were prepared initially in a threestep process of mechanical polishing, dry etching, and deposition of a $2 \mu \mathrm{m} \mathrm{GaN}$ : Si buffer layer in the 
MOVPE reactor. Recently, the two-step procedure is employed, which consists of mechanical polishing and mechano-chemical polishing. For growth, samples with different shapes were attached by indium to two inch $\mathrm{GaN} / \mathrm{Al}_{2} \mathrm{O}_{3}$ templates. The back surfaces of the two inch $\mathrm{GaN} / \mathrm{Al}_{2} \mathrm{O}_{3}$ templates were coated with a $0.7 \mu \mathrm{m}$ molybdenum layer to improve the thermal coupling for radiative heating. The typical size of GaN bulk high pressure substrates was $4 \times 5 \mathrm{~mm}^{2}$, while bulk HVPE substrates were $10 \times 10 \mathrm{~mm}^{2}$.

For PAMBE, the highest quality InGaN structures on $c$-plane (0001) surface are grown in the Inrich growth regime $[7,9,11,12]$. It was already demonstrated $[11,12]$ that the decrease in the growth temperature, $T_{\mathrm{G}}$, by reducing the decomposition of InN-fraction, can be used effectively to increase In content in the layers. However, reduction of $T_{G}$ can deteriorate the layer quality due to the reduction of surface adatom mobility [13]. Therefore, we propose an alternative path to achieve high In content layers - by increase of the nitrogen flux which can improve InN stability at higher temperatures.

\section{Optical lasing}

The laser structures for optical pumping were grown on HVPE bulk substrates with the dislocation density of $10^{6}-10^{7} \mathrm{~cm}^{-2}$. The structures consist of $0.5 \mu \mathrm{m}$ $\mathrm{Al}_{0.08} \mathrm{Ga}_{0.92} \mathrm{~N}$ bottom cladding followed by a $400 \mathrm{~nm}$

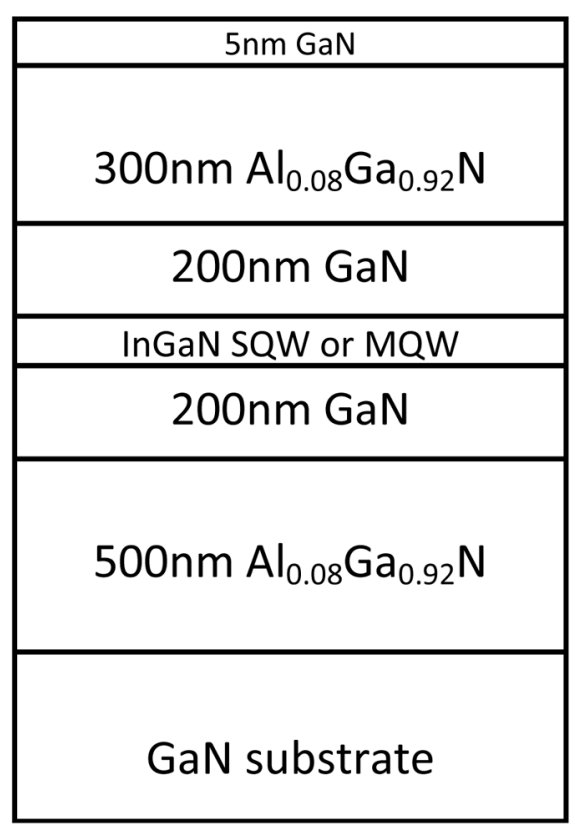

Fig. 1. The details of the structure grown for optical lasing.

GaN waveguide. The active region located in the middle of the waveguide consists of one or three $\mathrm{In}_{x}$ $\mathrm{Ga}_{1-x} \mathrm{~N}$ QW with a thickness from 2.2 to $3.5 \mathrm{~nm}$ and $10 \mathrm{~nm} \mathrm{In}{ }_{0.06} \mathrm{Ga}_{0.94} \mathrm{~N}$ barriers. The upper $\mathrm{Al}_{0.08} \mathrm{Ga}_{0.92} \mathrm{~N}$ cladding has a thickness of $0.3 \mu \mathrm{m}$ and structures were capped by a $5 \mathrm{~nm} \mathrm{GaN}$ layer. The details of the laser structure are shown in Fig. 1. In Fig. 2(a), we compare optical spectra below and above the lasing

(a)

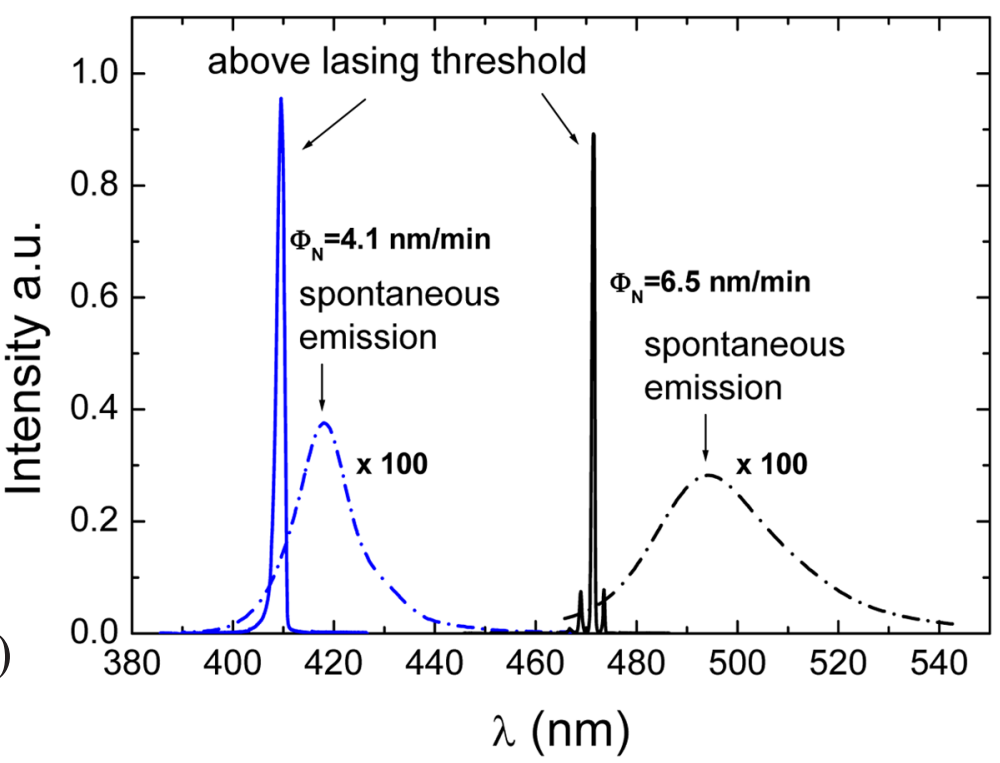

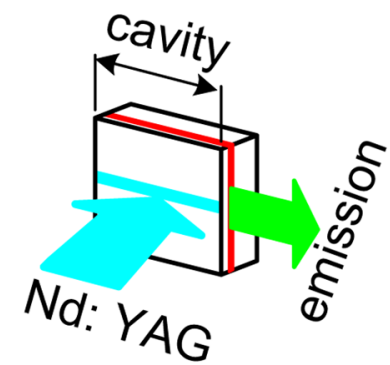

(b)

Fig. 2. The photoluminescence and lasing spectra of two laser structures: (a) optimised for lasing at 409 and $472 \mathrm{~nm}$, and (b) experimental geometry with Nd:YAG pumping laser. 
threshold for two structures, with QWs optimised for emission around 420 and $495 \mathrm{~nm}$. We achieved optically pumped lasing from these structures at 409 and $472 \mathrm{~nm}$, respectively [13]. The optical lasing was obtained from cleaved laser stripes with length $L=0.4-1.2 \mathrm{~mm}$ excited by the third harmonics $(355 \mathrm{~nm})$ of Nd:YAG laser beam with the aperture size of $0.25 \mathrm{~mm}$ (see Fig. 2(b) for experimental configuration details). The laser pulses had the duration of $5 \mathrm{~ns}$ and the repetition rate of $20 \mathrm{~Hz}$. The structure which lased at $409 \mathrm{~nm}$ was grown with $\mathrm{N}$ flux $4.1 \mathrm{~nm} / \mathrm{min}$, while the one lasing at $472 \mathrm{~nm}$ was grown with higher $\mathrm{N}$ flux $-6.5 \mathrm{~nm} / \mathrm{min}$, using otherwise nominally identical growth conditions. The lasing emission intensity as a function of the pumping power is shown in Fig. 3. It is clear that we are able to achieve lasing at $409 \mathrm{~nm}$ much earlier than at $472 \mathrm{~nm}$. Although better optical efficiency of QW for the $409 \mathrm{~nm}$ laser cannot be ruled out, we attribute this effect primarily to the superior light confinement in the waveguide at shorter wavelength (same design for both lasers).

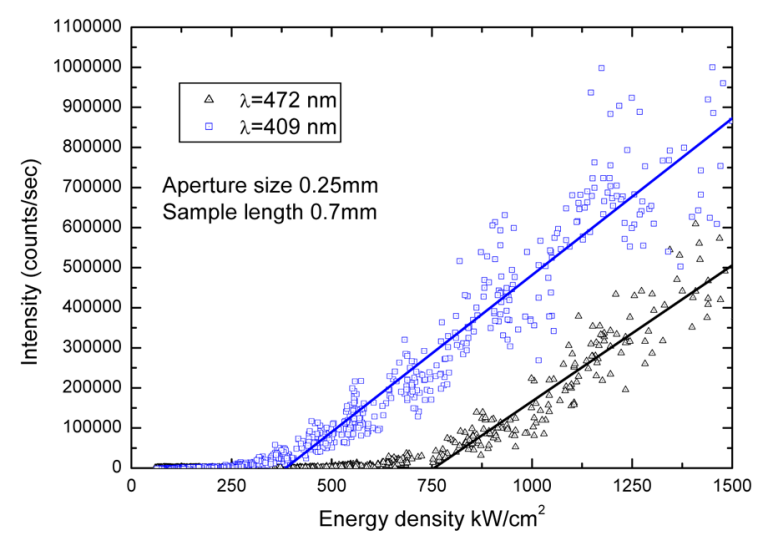

Fig. 3. The light-power characteristics for structures lasing at 409 and $472 \mathrm{~nm}$.

The largest available active nitrogen flux for the nitrogen plasma source initially mounted on our MBE system was $6.5 \mathrm{~nm} / \mathrm{min}$, sufficient to grow the above-discussed structure lasing at $472 \mathrm{~nm}$. After upgrading the MBE system with a second RF plasma source, the maximum nitrogen flux of $14 \mathrm{~nm} / \mathrm{min}$ became available. This allowed us to further shift the PL emission towards the green region while maintaining high growth temperature of InGaN. In Fig. 4,

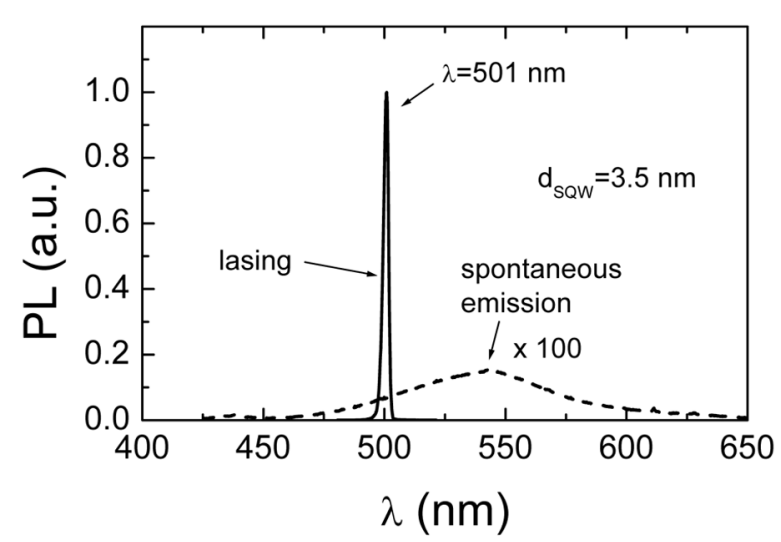

Fig. 4. The photoluminescence and lasing spectra at $501 \mathrm{~nm}$ for SQW structure with the thickness of $3.5 \mathrm{~nm}$.

we demonstrate spontaneous and stimulated emission from SQW laser structures with quantum well width of $3.5 \mathrm{~nm}$ grown at the highest nitrogen flux of $11 \mathrm{~nm} / \mathrm{min}$. The increase of the nitrogen flux during the growth of the active InGaN region allowed us to obtain a better optical quality of QWs and achieve lasing at $501 \mathrm{~nm}$ [13]. This is an indication that in PAMBE there are no fundamental limits to achieve enough efficient QWs for long wavelength lasers. Therefore, the laser diode design to reduce light losses starts to be essential.

\section{Laser diodes}

Laser diode structures were grown on (0001) Gapolarity, conductive GaN substrates. Two types of GaN substrates were used: (i) low dislocation density, below $10^{4} \mathrm{~cm}^{-2}$, high pressure-grown, and (ii) HVPE with the dislocation density of $10^{6}-10^{7} \mathrm{~cm}^{-2}$. For the lasers at $405-420 \mathrm{~nm}$, we used the structure shown in Fig. 5. The $40 \mathrm{~nm}$ GaN:Si buffer layer and $450 \mathrm{~nm} \mathrm{Al}{ }_{0.08} \mathrm{Ga}_{0.92} \mathrm{~N}: \mathrm{Si}$ cladding were grown under Ga-rich conditions at $720{ }^{\circ} \mathrm{C}$. The bottom waveguide, MQWs, EBL, top waveguide, top cladding, and contact layer were grown under In-rich conditions at $650{ }^{\circ} \mathrm{C}$. The active region consisted of three $3 \mathrm{~nm} \mathrm{In} \mathrm{In}_{0.1} \mathrm{Ga}_{0.9} \mathrm{~N}$ wells with $7 \mathrm{~nm} \mathrm{In}{ }_{0.02} \mathrm{Ga}_{0.98} \mathrm{~N}$ barriers. The devices were processed as ridge-waveguide, oxide-isolated lasers. The mesa structures were etched to a depth of $0.3 \mu \mathrm{m}$. The $20 \mu \mathrm{m}$ - wide and $500 \mu \mathrm{m}$-long stripes were used as laser resonators. The oxidised $\mathrm{Ni} / \mathrm{Au}$ ohmic contacts were deposited on the top surface 


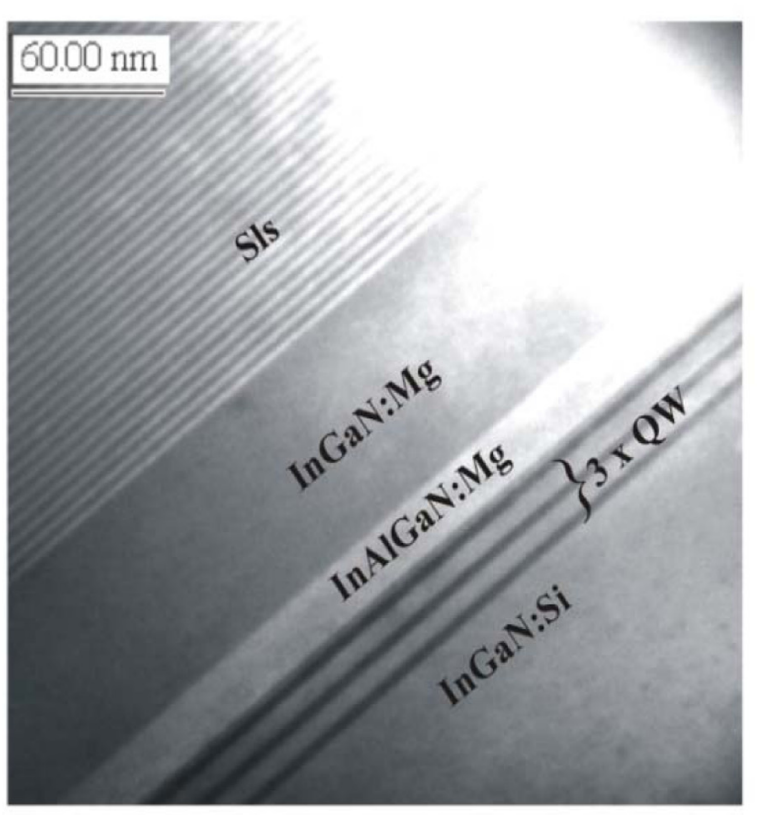

(a) (b)

\begin{tabular}{|c|}
\hline $\mathrm{In}_{0.1} \mathrm{GaN}: \mathrm{Mg} 3 \mathrm{~nm}$ \\
\hline $\mathrm{In}_{0.02} \mathrm{GaN}: \mathrm{Mg} 14 \mathrm{~nm}$ \\
\hline $\mathrm{In}_{0.02} \mathrm{GaN}: \mathrm{Mg} 2.5 \mathrm{~nm} /$ \\
$\mathrm{In}_{0.02} \mathrm{Al}_{0.18} \mathrm{GaN}: \mathrm{Mg} 2.5 \mathrm{~nm}$ \\
$60 \mathrm{SL}$
\end{tabular}

Fig. 5. (a) Transmission electron microscope image of the active region of a PAMBE laser diode. (b) Structure details.

of the devices, and $\mathrm{Ti} / \mathrm{Au}$ contacts were deposited on the backside of the highly conducting $n-G a N$ substrate crystal. The cleaved laser mirror facets were coated with symmetrically reflecting mirrors. Figure 6(a) shows the light-current-voltage $(L-I-V)$ characteristics of the CW LDs with the lasing threshold current density and voltage of
$5.5 \mathrm{kA} / \mathrm{cm}^{2}$ and $5.7 \mathrm{~V}$, respectively. Lasing was observed up to $60 \mathrm{~mW}$ of optical output power (30 mW per facet) at a wavelength of $411 \mathrm{~nm}$ as indicated in Fig. 6(b) [6]. This confirms that the growth of high quality layers by PAMBE has been achieved - the smooth interfaces required for LDs can be obtained as shown in Fig. 5(a).
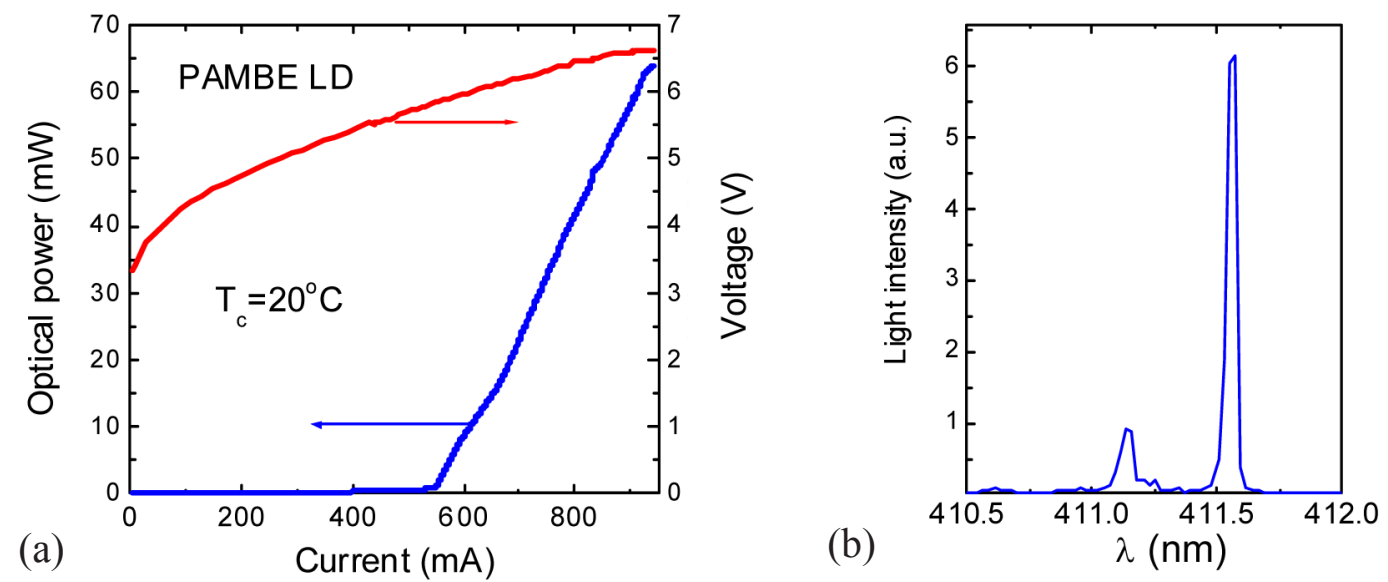

Fig. 6. (a) $L-I-V$ characteristics of PAMBE-grown cw laser diode. (b) Lasing spectrum. 


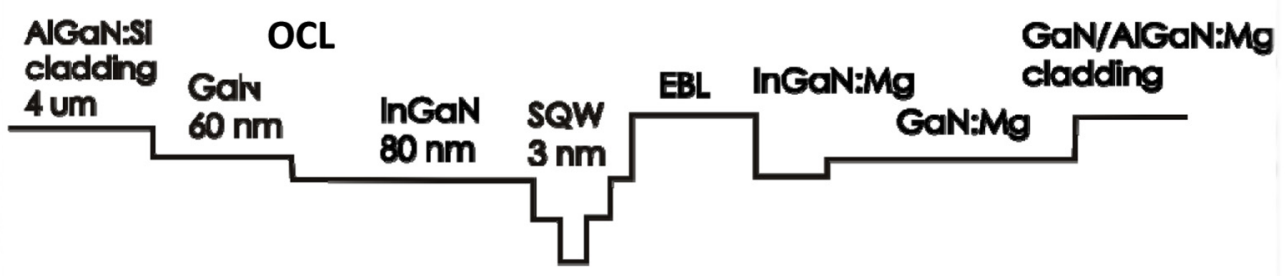

Fig. 7. Structure details of SQW $455 \mathrm{~nm}$ laser diode.

The optically pumped stimulated emission at $501 \mathrm{~nm}$ was a good starting point for true blue and green laser diodes. It is worth to stress here that not only efficient QWs are essential for LDs, but also the design of LDs ensuring confinement of the optical modes inside the laser waveguide. For the LDs operating at wavelengths longer than $430 \mathrm{~nm}$, we found that the crucial factor for achieving lasing is the optimisation of claddings and the waveguide. The details of single quantum well (SQW) LD structure lasing at $455 \mathrm{~nm}$ are presented in Fig. 7.

The true blue laser diodes have been grown on HVPE GaN substrates. In order to reduce penetration of the optical modes into the HVPE substrate (which has a rather low electron concentration $-5 \cdot 10^{17} \mathrm{~cm}^{-3}$ ), we have grown special claddings comprised of $2 \mu \mathrm{m}$ heavily doped $\mathrm{GaN}$ :Si at the level of $7 \cdot 10^{19} \mathrm{~cm}^{-3}$ and $4 \mu \mathrm{m} \mathrm{GaN} / \mathrm{Al}_{0.05} \mathrm{Ga}_{0.95} \mathrm{~N}$ super-

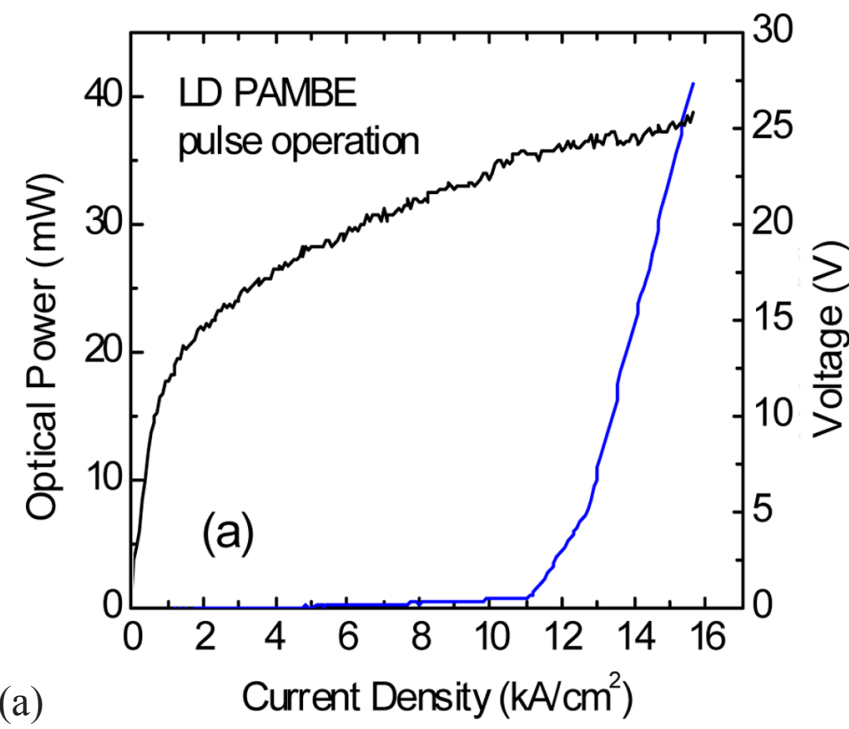

lattice. The heavily doped GaN:Si having the lattice constant close to $\mathrm{GaN}$ acts as plasmonic cladding [14]. For further localisation of the optical mode inside the waveguide and to reduce loses in the gold ptype contact, we also used the "optical confinement layer" (OCL) - $80 \mathrm{~nm}$ of $\operatorname{In}_{0.07} \mathrm{Ga}_{0.93} \mathrm{~N}$, and changed the upper cladding from InGaN/InAlGaN to $\mathrm{GaN} /$ $\mathrm{AlGaN}$ (see Fig. 7). As it comes out from theoretical calculations, the new claddings and waveguide with the OCL helped significantly (i) to decrease absorption of the optical modes in the upper gold contact, and (ii) to reduce penetration of the optical modes to the GaN HVPE substrate. Another interesting feature of SQW LDs grown by PAMBE is a relatively small blue shift from spontaneous (at $465 \mathrm{~nm}$ ) to lasing emission (at $455 \mathrm{~nm}$ ) - Fig. 8(b). This is achieved by employing the OCL and staggered SQWs which reduce piezoelectric fields inside the SQW.

Fig. 8. (a) $L-I-V$ characteristics of PAMBE-grown $455 \mathrm{~nm}$ SQW laser diode operating in a pulse mode. (b) Spectrum below and above the lasing threshold. 


\section{Conclusions}

In this work, we demonstrated recent progress in plasma assisted MBE technology for the growth of nitride-based laser diodes. We presented optically pumped structures operating from $410 \mathrm{~nm}$ to $501 \mathrm{~nm}$ and laser diodes in the spectral range from 410 to $455 \mathrm{~nm}$. As can be seen from these results, there is no obvious barrier in extending a MBE-grown laser diodes' spectral range into longer wavelengths. Thus, the long-term prospects for PAMBE in this area appear to be as good as for MOVPE.

\section{Acknowledgements}

This work was partially supported by the Polish Ministry of Science and Higher Education Grant No IT 13426, the European Union within the European Regional Development Fund, through grant Innovative Economy (POIG.01.01.02-00-008/08) and SINOPLE project.

\section{References}

[1] S. Nakamura, G. Fasol, and S.J. Pearton, The Blue Laser Diode: The Complete Story, 2nd ed. (SpringerVerlag, 2000).

[2] T. Jang, O.H. Nam, K.H. Ha, S.N. Lee, J.K. Son, H.Y. Ryu, K.S. Kim, H.S. Paek, Y.J. Sung, H.G. Kim, S.H. Chae, Y.H. Kim, and Y. Park, Recent achievements of AlInGaN based laser diodes in blue and green wavelength, Proc. SPIE 6473, 64730X (2007).

[3] C. Wetzel and T. Detchprom, Development of high power green light emitting diode chips, MRS Internet J. Nitride Semicond. Res. 10, 2 (2005).

[4] T. Miyoshi, S. Masui, T. Okada, T. Yanamoto, T. Kozaki, S. Nagahama, and T. Mukai, 510-515 nm InGaN-based green laser diodes on $c$-plane $\mathrm{GaN}$ substrate, Appl. Phys. Express 2, 062201 (2009).

[5] Y. Yoshizumi, M. Adachi, Y. Enya, T. Kyono, S. Tokuyama, T. Sumitomo, K. Akita, T. Ikegami, M. Ueno, K. Katayama, and T. Nakamura, Continuouswave operation of $520 \mathrm{~nm}$ green InGaN-based laser diodes on semi-polar $\{20 \overline{2} 1\} \mathrm{GaN}$ substrates, Appl. Phys. Express 2, 092101 (2009).
[6] C. Skierbiszewski, P. Wiśniewski, M. Siekacz, P. Perlin, A. Feduniewicz-Zmuda, G. Nowak, I. Grzegory, M. Leszczyński, and S. Porowski, $60 \mathrm{~mW}$ continuous-wave operation of InGaN laser diodes made by plasma-assisted molecular-beam epitaxy, Appl. Phys. Lett. 88, 221108 (2006).

[7] C.Skierbiszewski, Z.R. Wasilewski, I. Grzegory, and S. Porowski, Nitride-based laser diodes by plasmaassisted MBE - from violet to green emission, J. Cryst. Growth 311, 1632 (2009).

[8] C.R. Elsass, I.P. Smorchkova, B. Heying, E. Haus, P. Fini, K. Maranowski, J.P. Ibbetson, S. Keller, P.M. Petroff, S.P. DenBaars, U.K. Mishra, and J.S. Speck, High mobility two-dimensional electron gas in $\mathrm{AlGaN} / \mathrm{GaN}$ heterostructures grown by plasma-assisted molecular beam epitaxy, Appl. Phys. Lett. 74, 3528 (1999).

[9] J. Neugebauer, T.K. Zywietz, M. Scheffler, J.E. Northrup, H. Chen, and R.M. Feenstra, Adatom kinetics on and below the surface: the existence of a new diffusion channel, Phys. Rev. Lett. 90, 056101 (2003).

[10]J.E. Northrup, J. Neugebauer, R.M. Feenstra, and A.R. Smith, Structure of GaN(0001): the laterally contracted Ga bilayer model, Phys. Rev. B 61, 9932 (2000).

[11]H. Riechert, R. Averbeck, A. Graber, M. Schienle, U. Strauss, and H. Tews, MBE growth of (In)GaN for LED applications, Mater. Res. Soc. Symp. Proc. 449, 149 (1996).

[12] M. Siekacz, A. Feduniewicz-Zmuda, G. Cywinski, M. Krysko, I. Grzegory, S. Krukowski, K.E. Waldrip, W. Jantsch, Z.R. Wasilewski, S. Porowski, and C. Skierbiszewski, Growth of InGaN and InGaN/ InGaN quantum wells by plasma-assisted molecular beam epitaxy, J. Cryst. Growth 310, 3983 (2008).

[13] M. Siekacz, M. Sawicka, H. Turski, G. Cywiński, A. Khachapuridze, P. Perlin, T. Suski, M. Boćkowski, J. Smalc-Koziorowska, M. Kryśko, R. Kudrawiec, M. Syperek, J. Misiewicz, Z. Wasilewski, S. Porowski and C. Skierbiszewski, Optically pumped $500 \mathrm{~nm}$ InGaN green lasers grown by plasma-assisted molecular beam epitaxy, J. Appl. Phys. 110, 063110 (2011).

[14] P. Perlin, K. Holc, M. Sarzyński, W. Scheibenzuber, Ł. Marona, R. Czernecki, M. Leszczyński, M. Bockowski, I. Grzegory, S. Porowski, G. Cywiński, P. Firek, J. Szmidt, U. Schwarz, and T. Suski, Application of a composite plasmonic substrate for the suppression of an electromagnetic mode leakage in InGaN laser diodes, Appl. Phys. Lett. 95, 261108 (2009). 
InAIGaN LAZERINIAI DIODAI, AUGINAMI PLAZMA PAPILDOMO MOLEKULINIO SPINDULIO EPITAKSIJOS BŪDU

\author{
C. Skierbiszewski ${ }^{\mathrm{a}, \mathrm{b}}$, M. Siekacz ${ }^{\mathrm{a}, \mathrm{b}}, \mathrm{H}$. Turski ${ }^{\mathrm{a}}$, M. Sawicka ${ }^{\mathrm{a}}, \mathrm{A}$. Feduniewicz-Żmuda ${ }^{\mathrm{a}}$, P. Perlin ${ }^{\mathrm{a}, \mathrm{b}}$, \\ T. Suski a , Z. Wasilewski ${ }^{\text {c }}$ I. Grzegory ${ }^{\text {a }}$, S. Porowski ${ }^{\text {a }}$ \\ ${ }^{a}$ Lenkijos mokslu akademijos Didelio slègio fizikos institutas, Varšuva, Lenkija \\ ' TopGaN Ltd, Varšuva, Lenkija \\ 'Nacionalinés mokslo tarybos Mikrostruktūriniu moksly institutas, Otava, Kanada
}

\begin{abstract}
Santrauka
Aprašyti naujausi pasiekimai auginant nitrido pagrindo lazerinius diodus (LD) plazma papildomo molekulinio spindulio epitaksijos būdu (angl. plasma assisted molecular beam epitaxy, PAMBE). Šioje technologijoje nenaudojamas amoniakas, o auginimui reikalingą azotą iš azoto molekulių aktyvuoja radijo dažninis plazmos šaltinis. Nuolatinio švytejjimo mèlynai violetinių InGaN LD sukūrimas atvèrè naują perspektyvą naudoti PAMBE elektronikoje.
\end{abstract}

Pademonstruoti lazeriniai diodai, išauginti PAMBE būdu, veikiantys 410-455 nm srityje. Pagrindiniai veiksniai, leidžiantys pailginti lazerinès šviesos bangą iki 455 nm, yra (a) InGaN kvantinių šulinių auginimo patobulinimai esant dideliam azoto srautui naudojant PAMBE ir (b) lazerinio diodo konstrukcija. Taip pat pranešama apie optiškai žadinamą lazerinę $501 \mathrm{~nm}$ emisiją InGaN dariniuose, o tai reiškia, kad nèra vidinių kliūčių išauginti žalios šviesos LD naudojant PAMBE technologiją. 